\title{
IMAGE, FORM AND TRANSFORMATION. A SEMANTIC TAXONOMY OF PAUL'S "MORPHIC" LANGUAGE
}

George H. van Kooten

This paper examines Paul's language of the image of God. ${ }^{1}$ The notion of the image of God in Paul is, of course, part of his Adam Christology, which has been highlighted by James Dunn, especially in his Christology in the Making and his The Theology of Paul the Apostle. ${ }^{2}$ The most explicit occurrences of this Adamic Christology, in which Adam and Christ, the second Adam, are put on a par, are found in 1 Cor. 15:21-22, 45-47 and Rom. 5:12-19, where Adam is mentioned by name. ${ }^{3}$ The first passage reads:

For since death came through a human being, the resurrection of the dead has also come through a human being; for as all die in Adam, so all will be made alive in Christ. (1 Cor. 15:21-22) ${ }^{4}$

This contrast is elaborated upon in Romans 5. There Paul sketches a similar opposition between the man through whom $\sin$ and death came into the world, and the other man, of whom the first was a type or prototype; through this latter man grace, righteousness and life were imparted to many (Rom. 5:12-19). This reads like an elaboration of 1 Cor. 15:21-22. At the end of 1 Corinthians 15, however, it is precisely the contrast between Adam and Christ that is further highlighted. In this second Corinthian passage, the contrast between both human beings is repeated, but now worded explicitly in terms of the first and second man, the man from the earth and the man from heaven:

Thus it is written, "The first man, Adam, became a living being"; the last Adam became a life-giving spirit. But it is not the spiritual that is

\footnotetext{
'I wish to thank Dr Maria Sherwood-Smith for her correction of the English of this paper.

${ }^{2}$ J.D.G. Dunn, Christology in the Making. A New Testament Inquiry into the Origins of the Doctrine of the Incarnation, London 1989², id., The Theology of Paul the Apostle, Edinburgh 1998.

${ }^{3}$ See 1 Cor. 15:22, 45 and Rom. 5:14.

${ }^{4}$ Biblical translations are taken from the New Revised Standard Version, with minor alterations when necessary.

(C) GEORGE H. VAN KOOTEN, 2008 | DOI:10.1163/9789047443469_012

This is an open access chapter distributed under the terms of the CC BY-NC-ND 4.o license.
} 
first, but the physical, and then the spiritual. The first man was from the earth, a man of dust; the second man is from heaven. As was the man of dust, so are those who are of the dust; and as is the man of heaven, so are those who are of heaven. Just as we have borne the image of the man of dust, we will also bear the image of the man of heaven. (1 Cor. 15:45-49)

This passage reveals that the notion of the image of God also belongs to the core of Paul's Adam Christology. Dunn has argued that Paul develops his Adam Christology not only in the above passages from 1 Corinthians 15 and Romans 5, but throughout his letters. I agree with him that "Adam plays a larger role in Paul's theology than is usually realized," that "Adam is a key figure in Paul's attempt to express his understanding both of Christ and of man," and that "it is necessary to trace the extent of the Adam motif in Paul if we are to appreciate the force of his Adam Christology." In this paper I wish to contribute to this search by focusing on the semantic field of the image of God, which is part of Paul's Adam Christology. It seems that the semantic-conceptual field of the notion of the image of God is larger and more coherent than is often realized.

In this paper I shall argue that the notion of the image of God not

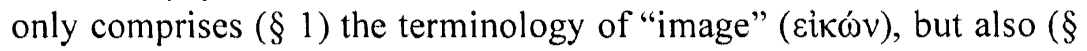

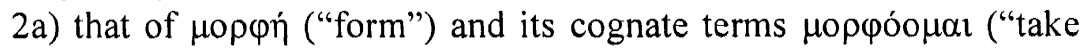

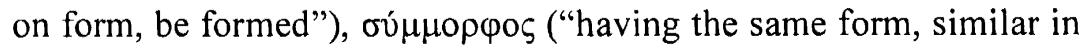
form"), $\sigma 0 \mu \mu о \rho \varphi i \zeta o \mu \alpha l$ ("be conformed to, take on the same form as"), and, last but not least, $\mu \varepsilon \tau \alpha \mu \rho \rho \varphi o_{0} \mu \alpha$ ("be transformed, be changed into the same form"). As regards the latter word, Dunn does not seem to realize that this verb is part of the image of God language. Instead, as we shall see in due course, he refers to a triple background of this notion in (a) the idea of metamorphosis which is deemed "common to many religious strands of the ancient world," (b) the language of moral transformation, and (c) a Jewish apocalyptic usage of the idea of transformation. ${ }^{6}$ Yet, as I shall suggest after a comparison between Paul and Philo ( $\S 2 b$ ), it is far more likely that Paul's use of the concept of metamorphosis does not owe much to either Greek or Jewish-apocalyptic ideas of transformation, but should be seen in the context of his reflections on God's image. In

\footnotetext{
${ }^{5}$ Dunn, Christology in the Making, p. 101.

${ }^{6}$ See Dunn's commentary on Rom. 12:2; J.D.G. Dunn, Romans 2, Dallas 1988, p. 713.
} 
general terms, the simple background seems to be that images have forms (as will be argued in $\S 2 \mathrm{c}$ ).

This approach gives rise to a more precise semantic taxonomy of Paul's concept of the image of God. As regards Paul's Adam Christology, Gordon Fee, in his recent Pauline Christology convincingly concludes:

So Adam Christology there is in Paul's thought, to be sure; but in terms of actual language and echoes from Gen 1-2, it is limited to two kinds of passages: first, explicit contrasts between Christ and Adam ...; and, second, where the incarnate Christ is seen as the true bearer of the divine image, who is also re-creating a people who bear that image with him. $^{7}$

Fee himself adopts the centre ground between "a minimalist position, which deals only with the three passages where Adam is specifically mentioned" (see above) and "a maximalist position, such as one finds in the work of J.D.G. Dunn or N.T. Wright"; Fee's position is "based on what appear to be certain connections made by Paul between Christ and the actual language of Gen. 1-3." ${ }^{\prime 8}$ This language consists of the terminology of the image of God.

Yet even if one agrees with Fee that Paul's Adam Christology should be based (primarily) on this language, the extent of this semantic field still remains to be charted. In his polemics with Dunn, Fee disputes, for instance, that in Phil. 2:6-8 $\mu о \rho \varphi \eta ं$ is virtually

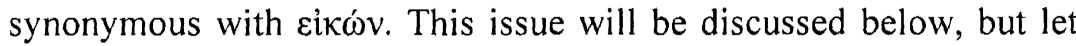
me point out in passing that Fee's criticism is ill-founded, since, on the contrary, the language of $\mu о р \varphi \eta$ is intrinsically linked with that of Eikǿv. As will be argued, the extent of the semantic and conceptual field of the divine image is larger than might be assumed at first glance; the scope of Paul's Adam Christology is extensive. The extent of this field is so large, and especially its inclusion of morphic language so important that, without much exaggeration, one could characterize Paul's Christology and anthropology as "morphic." This semantic taxonomy of only a part of Paul's Adam Christology shows that this type of Christology is indeed very dominant in Paul.

\footnotetext{
${ }^{7}$ G.D. Fee, Pauline Christology. An Exegetical-Theological Study, Peabody 2007, ch. 13: "Jesus as Second Adam," pp. 513-529, esp. 523.

${ }^{8}$ Fee, Pauline Christology, p. 513.
} 
The emphasis in this paper is on the detailed mapping of the semantic and conceptual field of "image of God." I shall, however, draw on the interpretation of the image of God in ancient Judaism, either by way of comparison or contrast, wherever this seems appropriate.

\section{The Terminology of Image}

I shall first give a brief survey of the actual occurrences of the terminology of $\varepsilon i \kappa \omega v$ in Paul's extant writings, roughly according to what seems to be the most likely chronological order. As we shall

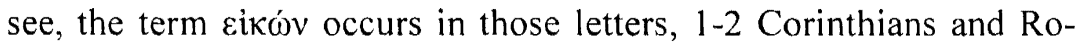
mans, which also contain Paul's explicit mentions of Adam.

In 1 Corinthians 11 , in his discussion of the need for women to veil their heads, Paul states that a man ought not to have his head

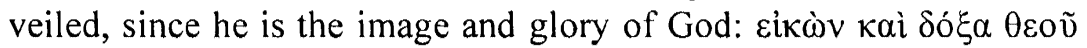
vं $\alpha$ $\rho \omega v$ (1 Cor. 11:7). This language clearly refers back to the image of God mentioned in Gen. 1:26-27. Later in 1 Corinthians 15, Paul again draws on this language when he explains that "Just as we have borne the image ( $\varepsilon i \kappa \omega v$ ) of the man of dust, we will also bear

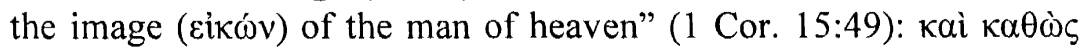

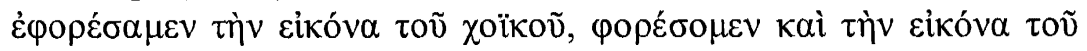
$\dot{\varepsilon} \pi$ oupavíov. As we learn from 2 Corinthians, where the language of

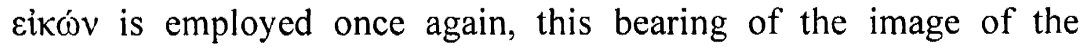
second Adam is not only an eschatological event. Rather, it involves a transformational process in the present, based on transformation into the image of Christ in his capacity -as 1 Corinthians 15

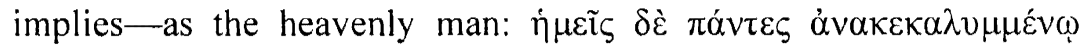

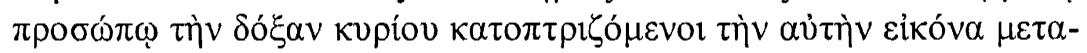

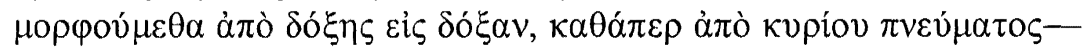
"And all of us, with unveiled faces, seeing the glory of the Lord as though reflected in a mirror, are being transformed into the same image from one degree of glory to another; for this comes from the Lord, the Spirit" (2 Cor. 3:18). The fact this image and glory are indeed Christ's is rendered explicit in the immediately succeeding

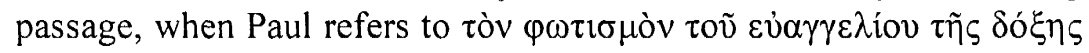

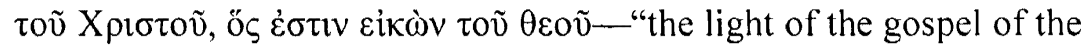
glory of Christ, who is the image of God" (2 Cor. 4:4). The glory of 
this Christ (2 Cor. $3: 18 ; 4: 4$ ), thus, is the glory of the second Adam, just as the first Adam was God's image and glory (1 Cor. 11:7).

The notion of the glory of Adam is reminiscent of the importance of this notion in the Dead Sea Scrolls. The language of Adam, whom God "fashioned in the likeness of [his] glory" and destined to "walk in a land of glory" (4Q504 frag. $84-7$ ), is applied to the members of the Qumran community: "to them shall belong all the glory of Adam" (1QS IV 23; cf. CD-A IV 20; $1 \mathrm{QH}^{\mathrm{a}}$ IV 15). Adam's glory is being reestablished in their community. Something similar is happening in the Christian community, according to 2 Corinthians 3-4. If people convert to Christ, the second Adam, and reflect his glory ( 2 Cor.

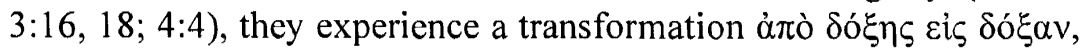
"from one degree of glory to another" (2 Cor. $3: 18)$. The language of the image and glory of God in 1-2 Corinthians is thus rooted in an ancient Jewish understanding of the image of God.

At the same time, as can be deduced from 1 Corinthians 15, Paul's mode of expression has been borrowed to some extent from pagan references to the images of the gods. When Paul writes that "Just as

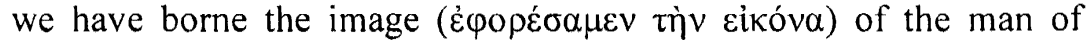
dust, we will also bear the image ( man of heaven" (1 Cor. 15:49), he avails himself of the imagery of carrying round a statue of a god. There are close analogies in the Greek Stoic philosopher Epictetus, for instance, according to whom man carries a god within him:

But they [i.e. all creatures other than man] are not of primary importance, nor portions of divinity. But you are a being of primary importance; you are a fragment of God; you have within you a part of Him. Why, then, are you ignorant of your own kinship? ... You are bearing

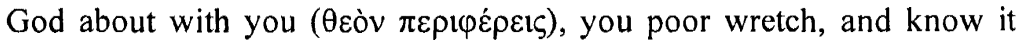
not! Do you suppose I am speaking of some external God? It is within

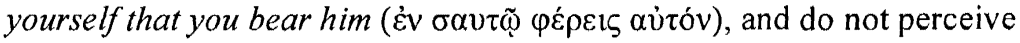
that you are defiling him with impure thoughts and filthy actions. Yet in

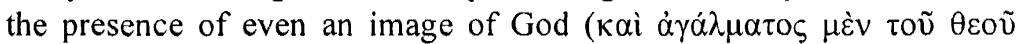
$\pi \alpha \rho v^{\prime} \tau$ Tos) you would not dare to do anything of the things you are now doing. (Discourses II 8:11-14) ${ }^{9}$

"Cf. J. Haussleiter, "Deus internus," RAC 3 (1957), pp. 794-842, esp. 807 with reference to Epictetus, Diss. II 8.11-14 and Marcus Aurelius, Meditations XII 23.6: "Auch das Adjektiv $\theta \varepsilon o \varphi o ́ p \eta t o \zeta$, von Gott getragen, verwendet Marc[us Aurelius] einmal $(12,23,6)$, das passive Korrelat zum Gottragen des Epiktet"; and pp. 810-811 with reference to lamblichus, De 
The internal act of carrying (the image of) God within oneself is contrasted with the external reverence paid to the visible statue of a god.

Another particularly instructive example can be found in Philo who, in his Legatio ad Gaium, explains in everyday pagan language what the Jews are doing:

Holding that the laws are oracles vouchsafed by God and having been trained in this doctrine from their earliest years, they carry as a statue

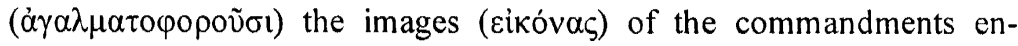
shrined in their souls. Then as they contemplate their shapes and forms

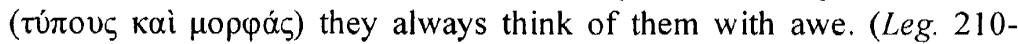
211)

Philo applies the language of the pagan practices of carrying round idols in a metaphorical way to the way in which Jews carry round the image of the law within their minds. In a similar way, I would suggest, Paul speaks of human beings carrying the image of God: first the distorted image of the first Adam, which is only in a remote sense still an image of God, but subsequently the image of the second Adam.

A similar antithesis between the images of idols and the image of God may be present in Paul's Romans, which contains the other oc-

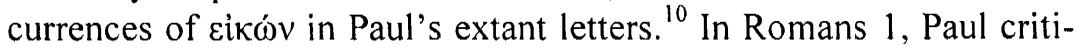
cizes those who have degenerated into idol-worshippers: "they exchanged the glory of the immortal God for images resembling a

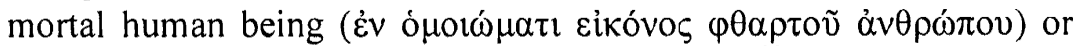
birds or four-footed animals or reptiles" (1:23). "In Romans, these

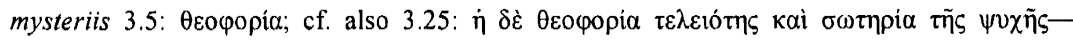
"divine $\theta \varepsilon о \varphi о \rho i \alpha$ is a perfection and deliverance of the soul" (trans. E.C. Clarke/J.M. Dillon/J.P. Hershbell, Iamblichus: De mysteriis. Translated with an Introduction and Notes, Atlanta 2003). Haussleiter takes the phrase "bearing God about with you ( $\theta \varepsilon \dot{v} v \pi \varepsilon \rho \iota \varphi \dot{\varepsilon} \rho \varepsilon 1 \varsigma)$ " in Epictetus, Discourses II 8.12 as a possible reference to the bearing of amulets. See Haussleiter, "Deus internus," p. 807: "Nach Dölger, ACh 4 (1934) 72 wird Epiktet hier an den "Gott" als Amulett gedacht haben." Translations of classical sources are normally taken from the Loeb Classical Library, with occasional small alterations.

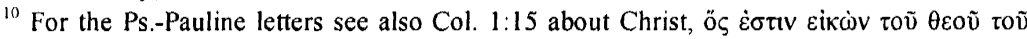

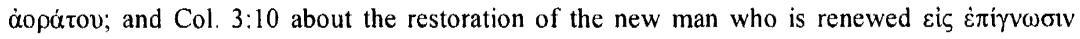

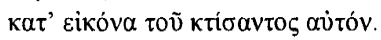

"For Paul's polemical purpose behind this passage, and behind the beginning of his letter in Romans 1, see G.H. van Kooten, "Pagan and Jewish Monotheism according to Varro, Plutarch and St Paul: The Aniconic, Monotheistic Beginnings of Rome's Pagan Cult-Romans 1:19-25 in a Roman Context," in: A. Hilhorst/É. Puech/E. Tigchelaar (eds), Flores Florentino. 
images of idols contrast sharply with the image of God's son, whose form God has predestined the readers to resemble: $\pi \rho \circ \omega \rho \iota \sigma \varepsilon \nu ~ \sigma 0 \mu-$

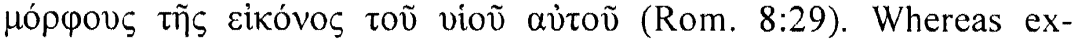
changing the glory of God for images of idols is a sign of mankind's decline, its restoration takes place when man is conformed to God's image.

This antagonism between the image of God and idols seems already to be part of the Old Testament background to the notion of the image of God. It is not unlikely that the assertion that man is created "in God's image" (Gen. 1:26-27) could bear anti-idolatrous overtones, as the term "image" (צלם) is one of the words used to refer to idols (Num. 33:52; 2 Kgs. 11:18; 2 Chron. 23:17; Ezek. 7:20; 16:17; 23:14; Amos 5:26). In this respect the priestly author of Genesis is resembled by Ezekiel (see Ezek. 1:26-28). As John Kutsko notes in his comments on the "image of God" in Ezekiel:

Ezekiel struggles to find appropriate language that indicates both human likeness and divine incomparability. The prophet directs his efforts in several directions: he is at once attempting to align himself with Priestly theology, to contradict Mesopotamian ideology, and to refrain from language that would explicitly legitimize the notion of other gods. Fundamentally, however, P and Ezekiel are dealing with the same answer, approached from different angles: humans are like God, and God is like humans. In this answer, both $\mathrm{P}$ and Ezekiel remove other gods from the equation. ${ }^{12}$

This polemical anti-idolatrous understanding of man as the image of God also surfaces in later sources. In a passage denouncing idolatry, the author of Sibylline Oracles III addresses mankind as follows:

Men, who have the form which God moulded in his image

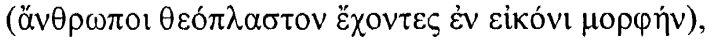

Why do you wander in vain, and not walk the straight path ever mindful of the immortal creator? (III 8-10)

Dead Sea Scrolls and Other Early Jewish Studies in Honour of Florentino Garcia Martine:, Leiden/Boston 2007, pp. 633-651.

12 J.F. Kutsko, "Ezekiel's Anthropology and Its Ethical Implications," in: M.S. Odell/J.T. Strong (eds), The Book of Ezekiel. Theological and Anthropological Perspectives, Atlanta 2000, pp. 119-141, esp. 132. On the idea of the image of God and the polemic against the idols of Ancient Near Eastern cults, see also A. Schüle, "Made in the 'Image of God': The Concepts of Divine Images in Gen 1-3," ZAW 117 (2005), pp. 1-20, esp. 1-2, 9-11. On P and Ezekiel, see also J.M. Miller, "In the 'Image' and 'Likeness' of God," JBL 91 (1972), pp. 289-304 at p. 303. 
As the passage continues by criticizing man-made idols (III 29-35), it is possible that this sentence hints at an opposition between the image of God and the other images of idolatrous cults, although here the

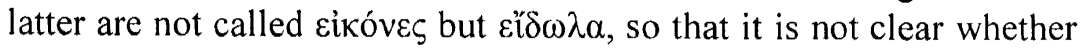
such a contrast is deliberately intended. A full-blown antithesis does come to the fore, however, in book VIII of the Sibylline Oracles. The passage in question is again part of a denunciation of idolatry (VIII 359-428), spoken by God himself; it develops an explicit antithesis

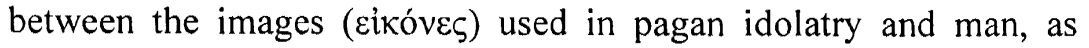

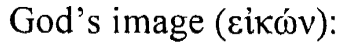

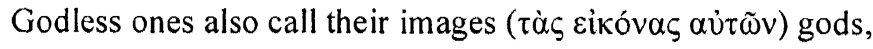
abandoning the Creator, thinking to have all hope and life from them. Trusting in dumb and speechless things with evil result, they are ignorant of good end.

I myself proposed two ways, of life and death, And proposed to the judgment to choose good life.

But they turned eagerly to death and eternal fire.

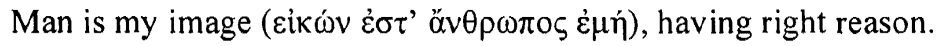
(VIII 395-402)

Here, the opposition between the images of the gods and the image which is man, endowed with right reason, is rendered explicit. In essence it is the same opposition as that already found within $\mathrm{P}$ and Ezekiel. The logical conclusion of this way of thinking, that man, in his capacity as God's image, is the only image of God and as such merits worship, is drawn in the Life of Adam and Eve (LAE). According to $L A E$, if Adam is the true image of God, he constitutes the proper object of worship, not by fellow human beings, but by the angels (LAE [Oriental and Latin versions] 13:1-15:3; 37:3; 39:1-3). This remarkable view-that Adam, in his capacity as the image of God, is to be worshipped as an idol by angels - could be taken as the most radical consequence of the extraordinary position accorded to man in the Priestly Source, and shows the inherent antithesis between this image and the alternative images of pagan cult.

This appears to be very similar to the antithesis which Paul draws between the images for which God's glory was exchanged and Christ, as the proper image of God, to which the Christians are being conformed. 
From this overview it emerges that in Paul's extant letters the

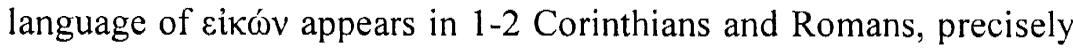
the letters in which the contrasting pair Adam and Christ occur, constituting Paul's explicit Adam Christology. This is no coincidence. The letters in which an explicit Adam Christology is unfolded also contain the designation of Adam as the image of God, be it Adam I or Adam II. Nor is it coincidental that these letters are addressed to largely pagan communities; in a letter within a Judaizing context, as Galatians shows, it is not Adam but rather Abraham who is the focus of attention.

\section{The Terminology of Forms}

\section{a. A Survey of Morphic Language in Paul}

Let me first draw attention to the two passages in Paul which

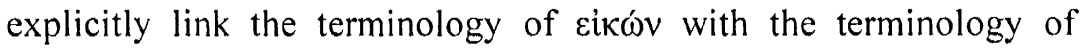
forms. In 2 Cor. 3:18, a passage already quoted above, Paul posits that "all of us," i.e. all Christ-believers, "with unveiled faces, seeing the glory of the Lord as though reflected in a mirror, are being transformed into the same image from one degree of glory to

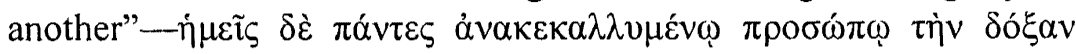

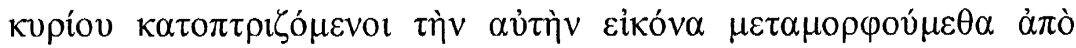
$\delta o ́ \xi \eta \zeta \varepsilon i \zeta \zeta \delta \delta \xi \alpha v$. Here, the language of image and form is linked inasmuch as a transformation or metamorphosis takes place into the image of God (cf. 2 Cor. 4:4). We shall return to the concept of metamorphosis below, in the discussion of Rom. 12:2, where this concept reoccurs. For now, it will suffice to highlight that the terminologies of image and form do indeed intersect.

This also appears to be the case in Rom. 8:29, also quoted above, when Paul says that God has predestined the Christ-believers to be

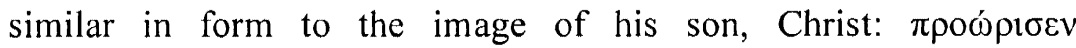

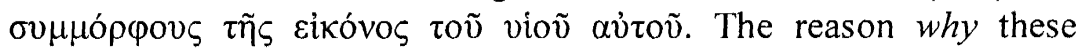
terminologies overlap has not yet been fully explored in scholarly debate, and will be established further below. First we shall continue with a survey of Paul's morphic language, identifying any particular features or exegetical problems encountered in a kind of inventory.

The notion of becoming similar in form to Christ that features in the passage in Romans just discussed also occurs, in reverse order, in 
Gal. 4:19: here it is not the believers who are said to be conformed to Christ, but rather Christ who will "receive form in you," the Gala-

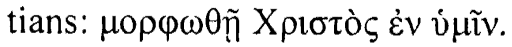

A very different use of morphic language seems to be involved in Phil. 2:6-7, in the well-known piece of hymnic prose known as the Philippian hymn. The readers are exhorted to be of one mind with

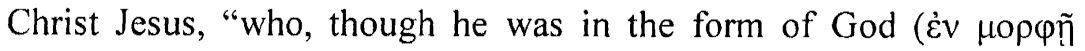
$\theta \varepsilon o \tilde{v}$ vं $\alpha \dot{\rho} \chi(\omega v)$, did not regard equality with God as something to be exploited, but emptied himself, taking the form of a slave ( $\mu$ орфүे

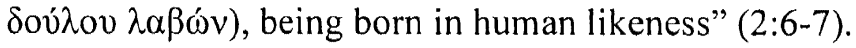

Paul's talk about God's form is closely matched by that of Josephus in his Contra Apionem. In a passage on the first commandment, in explaining the Jewish conception of God, Josephus writes:

What, then, are the precepts and prohibitions of our Law? They are simple and familiar. At their head stands one of which God is the theme. The universe is in God's hands; perfect and blessed, self-sufficing and sufficing for all, $\mathrm{He}$ is the beginning, the middle, and the end of all things. By His works and bounties $\mathrm{He}$ is plainly seen, indeed more manifest than ought else; but His form and magnitude surpass our

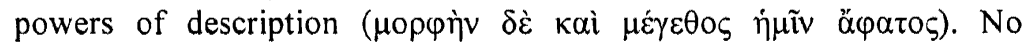
materials, however costly, are fit to make an image of $\operatorname{Him}(\pi \tilde{\alpha} \sigma \alpha \mu \dot{\varepsilon} v$

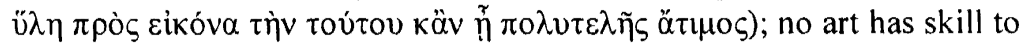
conceive and represent it. The like of Him we have never seen, we do

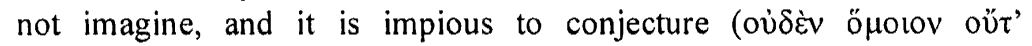

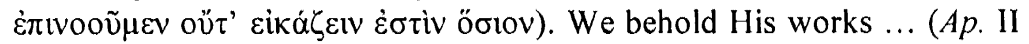
190-191)

According to Josephus, God does indeed possess a form, but this is $\ddot{\alpha} \varphi \alpha \tau o \zeta$, inexpressible. For this reason, no image of him can be made in the form of a statue. Josephus also emphasizes this later, in a passage in which he attacks the Greeks' gross and immoral ideas about the gods:

They have even deified Terror and Fear [Deimos and Phobos, attendants of Ares, Iliad XV 119], nay Frenzy and Deceit-which of the worst passions have they not transfigured into the nature and form of a god

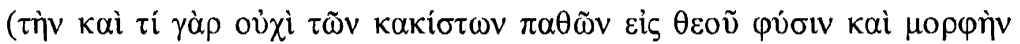
$\dot{\alpha} v \varepsilon \dot{\pi} \lambda \alpha \sigma \alpha v)$ ? - , and have induced cities to offer sacrifices to the more respectable members of this pantheon. (Ap. II 248). 
The ineffable form of the Jewish God is placed in sharp contrast with the form of idolatrous statues of the gods. Although Josephus does apply the term "form" to God, it seems to be for polemical, antiidolatrous reasons that he avoids speaking of God's cikஸ́v. As Jervell noted and Levison emphasized, Josephus never uses the concept of God's image, even not in his retelling of Genesis $1 .^{13}$ In this, he differs from both Philo and Paul. Yet his passage about the ineffable form of God shows that the terminology of form as such is related to that of image, even if the terms are contrasted in this particular context in Josephus' work. Josephus' view that no visual image can be made of God because his form surpasses our powers of description shows that, despite the opposition between the true God and idols, the language of form and image is inherently connected. There is talk about the form and image of God, even if the first is beyond description and the possibility of the latter is denied. Josephus" use of the term "form" seems to be an instance of his metaphorical use of language, similar to the cases in which he speaks of the forms of the visual statues of the gods, such as the second passage from his Contra Apionem.

The manner in which the terms of form and image intersect will be explored later, but it is important to stress that they do overlap and are part of the same semantic and conceptual field. This is important because the synonymy (or near-synonymy) or semantic-conceptual

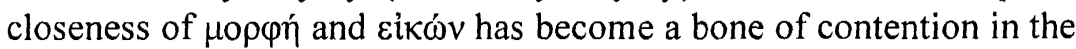
scholarly debate about Christology in the Philippian hymn. On the one hand, scholars such as Dunn claim that the phrase $\dot{\varepsilon} v \mu о \rho \varphi \tilde{n} \theta \varepsilon \circ \tilde{v}$ is part and parcel of Paul's Adam Christology, and point to Christ's being in the image of God. On the other hand, scholars such as Steenburg and Fee strongly contest this synonymy between form and image. ${ }^{14}$ The polemics have become heated, Fee making a philippica against those scholars who regard both terms as synonymous:

${ }^{13}$ J. Jervell, "Imagines und Imago Dei: aus der Genesis-Exegese des Josephus," in: O. Betz, K. Haacker/M. Hengel (eds), Josephus-Studien. Untersuchungen zu Josephus, dem antiken Judentum und dem Neuen Testament: Otto Michel zum 70sten Geburtstag gewidmet, Göttingen 1974, pp. 197-204, esp. 200-204; J.R. Levison, Portraits of Adam in Early Judaism. From Sirach to 2 Baruch, Sheffield 1988, pp. 101, 109, 147.

${ }^{14}$ See D. Steenburg, "The Case against the Synonymity of Morphē and Eikōn," JSNT 34 (1988), pp. 77-86 and Fee, Pauline Christology, pp. 522-523 and 377-379. 
There has been a veritable groundswell in the NT academy that has argued (or more often simply asserted) that Paul's use of $\mu о \rho \varphi \eta$ in the opening phrase of the Christ story (v. 6 [= Phil. 2:6]) is virtually

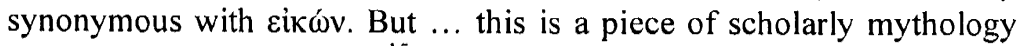
that needs to be laid to rest. ${ }^{15}$

It is true, I think, that Dunn and others have often emphasized that

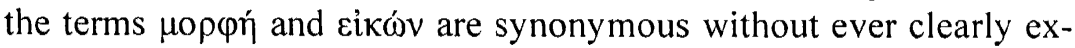
plaining why. Dunn almost takes the near-synonymy for granted,

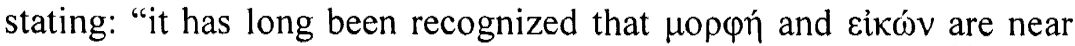
synonyms," with particular reference to the work of Martin. ${ }^{16}$ However, Martin before him also seems to be content with demonstrating

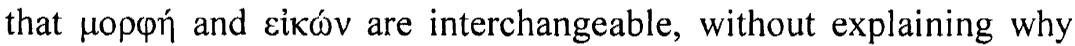
they belong to the same semantic-conceptual field: "because the terms appear to be used interchangeably in various contexts their meanings are to be regarded as equivalent." ${ }^{\prime 17}$ No specific background for this statement is given, except for a general reference to the Septuagint. This means the claim that $\mu о \rho \varphi \eta ́$ and sikóv are nearsynonyms lacks precision.

On the other hand, however, it seems unwarranted to emphasize a conceptual difference between the terms to the extent that Fee does. The passage from Josephus' Contra Apionem discussed above shows that $\mu о \rho \varphi \eta$ and cikóv belong to the same semantic-conceptual field (Ap. II 190-191). This should obviously be noted in the inventory, and in the next section we shall compare Paul's morphic language with that of Philo to establish whether Philo's use of morphic language can throw any light on the issue. Before that, however, we shall continue our survey of morphic passages in Paul.

Morphic language is also important in two other passages in Philippians. These passages also contain the notion of "having the

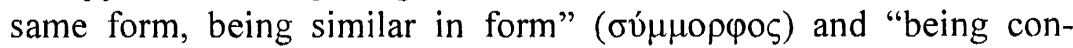
formed to, taking on the same form as" ( $\sigma \nu \mu \mu о \rho \varphi i \zeta o \mu \alpha \mathrm{l})$, as encountered already in both Rom. 8:29 and, in reverse form, in Gal. 4:19. In

\footnotetext{
${ }^{15}$ Fee, Pauline Christology, pp. 522-523, esp. 522; cf. pp. 377-379.

${ }^{16}$ Dunn, Christology in the Making, pp. 115 and 117; Dunn, The Theology of Paul, \$ 8.6, pp. 199-204. Dunn does clearly relate $\mu$ op in $\$ 11.4$, pp. 281-288 on Phil. 2:6-11; this is also a majority view, see p. 284 n. 83: "the semantic fields of the two terms overlap considerably."

${ }^{17}$ R.P. Martin, Carmen Christi. Philippians ii.5-11 in Recent Interpretation and in the Setting of Early Christian Worship, Cambridge 1967, pp. 102-120, esp. 118.
} 
Phil. 3:10, Paul expresses his ardent wish "to know Christ and the power of his resurrection and the sharing of his sufferings by taking

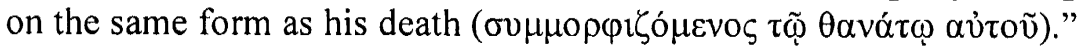
This Christ, as Phil. 3:21 explains, "will transform the body of our humiliation so that it may have the same form as the body of his

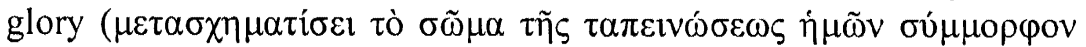

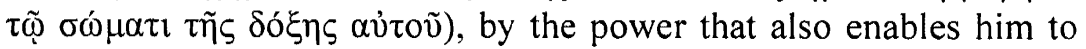
make all things subject to himself." Together with the passages from Rom. 8:29 and Gal. 4:19, these passages are testimony to the great importance which Paul attaches to the notion of having or taking on the same form as that of Christ. This is indeed a conformity to the form of Christ's عikǿv, as Rom. 8:29 makes explicit.

The last relevant morphic passage in Paul is Rom. 12:2. ${ }^{18}$ Here again, as in 2 Cor. 3:18, Paul mentions the phenomenon of metamorphosis. He exhorts his readers in the following manner: "Do not be conformed to this world, but be transformed $(\mu \varepsilon \tau \alpha \mu \circ \rho \varphi \circ v \tilde{\sigma} \theta \varepsilon)$ by the renewing of your minds, so that you may discern what is the will

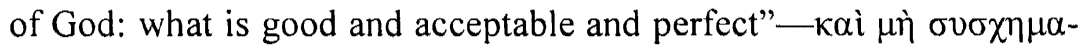

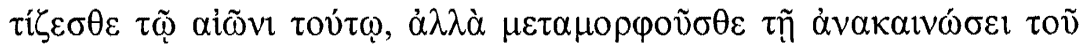

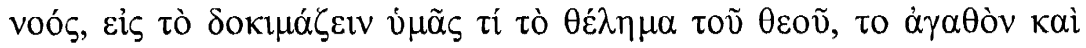

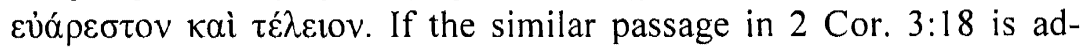
duced, this metamorphosis appears to be a metamorphosis into the image of God. This link between metamorphosis and image seems to be crucial and is another point for our inventory of problems, since the background of the notion of metamorphosis and its link with the terminology of image is not sufficiently clear.

Dunn, in his comments on metamorphosis in Rom. 12:2, refers to a threefold background of "metamorphosis." (1) First, Dunn points out that the "idea of metamorphosis is common to many religious strands of the ancient world, including the classic myths about the gods changing into earthly form, and accounts of individuals being transformed through mystery ritual or Gnostic release." (2) Sub-

\footnotetext{
${ }^{18}$ The only morphic passage which I leave out of consideration in this survey is Rom. $2: 20$. In this passage Paul describes the self-image of his Jewish opponent, who is confident that he is "a guide to the blind, a light to those who are in darkness, a corrector of the foolish, a teacher of children, having in the law the embodiment, the 'bringing into shape' ( $\mu$ ó $\rho \omega \sigma i \varsigma)$ of knowledge

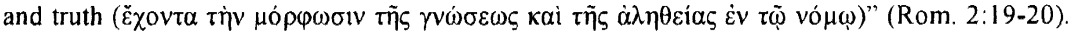
This morphic term seems to stand on its own. Cf. for the later Pauline letters, 2 Tim. 3:5.

${ }^{19}$ Dunn, Romans, p. 713.
} 
sequently, he specifies that this language ought not to imply "that Paul here is using 'mystery-conceptions'," as Richard Reitzenstein proposed, but that "the language could be used in the sense of a moral transformation." (3) Finally, Dunn draws upon the idea of metamorphosis in Jewish apocalyptic writings (1 En. 104:6; 4 Ezra $7: 97 ; 2$ Bar. 51:5). Surprisingly, Dunn does not consider the possibility that the language of metamorphosis in Paul is strongly related to the semantic-conceptual field of "image," even though the comparable passage of 2 Cor. 3:18 hints in this direction. The problem is that the background of the notion of metamorphosis in ancient mythology and Jewish apocalyptic is not sufficiently convincing. ${ }^{20}$ The Jewish apocalyptic sources do perhaps contain the idea of metamorphosis, but hardly the explicit terminology, whereas the specific terminology of metamorphosis in Greek is rather late, with only a limited number of occurrences before the first century CE. As T. Ballauff notes,

Das Wort "Metamorphose" begegnet uns in der griechischen Literatur spät. Die lateinische Sprache hat dafür das Wort "transfiguratio," das zuerst bei Plinius vorkommt; Seneca kennt schon "transfigurari." Die Vorstellung von der Verwandlung göttlicher oder menschlicher Wesen in Tiere, Pflanzen, Steine ist, wie in anderen Ländern, so auch in Griechenland uralt. P. Ovidius Naso ist nicht der erste gewesen, der in Rom Verwandlungssagen poetisch behandelte, sondern die Metamorphose-Dichtung hatte dort längst ihren Einzug genommen. ${ }^{21}$

If we look at Ovid's Metamorphoses, for instance, there are indeed some parallels with 2 Cor. 3:18 which are worth noting. In his account of the creation of man, Ovid stresses both the fact that man is made of the divine substance of the creator or, alternatively, that man is moulded into the form of the gods:

Natus homo est, sive hunc divino semine fecit

ille opifex rerum, mundi melioris origo,

\footnotetext{
${ }^{20}$ See $I$ En. 104:6: "Now fear not, righteous ones, when you see the sinners waxing strong and flourishing"; 4 Ezra 7:97: "their face is to shine like the sun, and (..) they are to be made like the light of the stars, being incorruptible from then on"; 2 Bar. 51:5: "those over whom they are exalted now will then be more exalted and glorified than they; (...) both these and those will be changed, these into the splendor of angels and those into startling visions and horrible shapes." Translations of Jewish pseudepigrapha are taken from J.H. Charlesworth (ed.), The Old Testament Pseudepigrapha 1-2, Garden City 1983-1985.

${ }_{21}^{21}$ T. Ballauff, "Metamorphose," Historisches Wörterbuch der Philosophie 5 (1980), pp. 1177-1179, esp. 1177.
} 
sive recens tellus seductaque nuper ab alto

aethere cognati retinebat semina caeli.

quam satus Iapeto, mixtam pluvialibus undis,

finxit in effigiem moderantum cuncta deorum.

Then man was born: whether the god who made all else, designing a more perfect world, made man of his own divine substance, or whether the new earth, but lately drawn away from heavenly ether, retained still some elements of its kindred sky-that earth which the son of Iapetus mixed with fresh, running water, and moulded into the form of the allcontrolling gods. (1 78-83)

Whereas the view that man is made of the creator's own divine substance comes close to the Jewish creation account of Genesis 1, according to which man was created "in the image of God," the other view that "the son of lapetus," Prometheus, moulded man from earth into the form of the gods resembles the creation account of Genesis 2 . These views are so compatible that, from the third century onwards, the imagery of Prometheus moulding man out of the earth was taken over by Christians and applied to the creation of Adam by God and Christ. ${ }^{22}$

Yet the inference which Paul draws from the Jewish creation accounts that man is being reshaped and experiences a transformation into the image of God has virtually no parallel in Ovid's anthropology. First of all, there are alternative, very different anthropologies in Ovid which seem to push aside the anthropology of I 78-83. According to these alternative anthropologies, offspring in "human

\footnotetext{
${ }^{22}$ See the Prometheus-sarcophagus of Rome/Arles (c. 270/280 CE), now in the Louvre, and the biblical sarcophagus of Rome/Arles (c. $325 \mathrm{CE}$ ), now in Arles, discussed in J. Engemann, "Nichtchristliche und christliche Ikonographie," in: A. Demandt/J. Engemann (eds), Konstantin der Grosse: Imperator Caesar Flavius Constantinus-Ausstellungskatalog, München 2007, pp. 281-294 at pp. 282-283. For Prometheus' creation of mankind, see Aristophanes, Aves 686; Plato, Protagoras 320d; Philemon, frag. 93 and Poetae Comici Graecae-Adespota, frag. 1047; Menander, frag. 508; Heraclides Pontus, frag. 66ab; Callimachus, frag. 493: Herondas II 28; Horace, Carmina I 16.13-16; Pausanias, Description of Greece X 4.4. For Late Antiquity see H. Kaiser-Minn, Die Erschaffung des Menschen auf den spätantiken Monumenten des 3. und 4. Jahrhunderts, Münster 1981; add now Pap.Lugd.Bat. XXV.16 (a fourth-century wax tablet with an alphabetic acrostic on Prometheus' creation of mankind); J. Balty/F. Briquel Chatonnet, "Nouvelles mosaïques inscrites d'Osrhoène," Monuments et Mémoires 79 (2000), pp. 31-72, esp. 39-41; G. Bowersock, "Notes on the New Edessene Mosaic of Prometheus," Hyperboreus 7 (2001), pp. 411-416; this bibliography was kindly provided by my colleague Jan N. Bremmer (Groningen), drawing on his Greek Religion \& Culture. The Bible and the Ancient Near East, Leiden/Boston 2008, p. 33 n. 65.
} 
form" was generated by Mother Earth from the blood of the slain Giants (I 156-160) or human beings evolved from the stones thrown by Deucalion and Pyrrha to produce a new human race after the Flood (I 400-415). These anthropologies in Ovid are in competition with one another. More importantly, however, the notion that human beings experience transformation seems to be limited to particular human beings, such as the emperor, or Heracles, son of a mortal woman and a god. At Heracles' death

\section{... nec cognoscenda remansit}

Herculis effigies, ne quicquam ab imagine ductum

matris habet, tantumque Iovis vestigia servat.

sic ubi mortales Tirynthius exuit artus, parte sui meliore viget, maiorque videri coepit et augusta fieri gravitate verendus.

... no shape of Hercules that could be recognized remained, nor was there anything left which he derived from his mother's image. He kept traces only of his father ...; so when the Tirynthian put off his mortal frame, he gained new vigour in his better part, began to seem of more heroic size, and to become awful in his godlike dignity. (IX 263-270)

Apart from Heracles, only the emperor, Julius Caesar, seems to experience a metamorphosis. It is Julius Caesar who is "changed to a new heavenly body, a flaming star" (XV 745; cf. XV 840-851), a fate which still awaits Augustus (XV 868-870).

From this it is clear that Ovid's Metamorphoses can render only a partial explanation for the concept of metamorphosis as adopted by Paul. For Ovid, the notion of metamorphosis constitutes a connecting link between various mythological cycles, and is supported by the philosophical or Pythagorean view that the soul "passes into everchanging bodies" (XV 60-478 at 171-172). It does not sufficiently explain Paul's thoughts about the metamorphosis of Christ-believers into the image of God. What Ovid's Metamorphoses do demonstrate, however, is that, in Ovid, too, the terminologies of image and form belong to the same semantic-conceptual field. In III 455-463, for instance, in a vivid description of Narcissus' self-obsession, the terminology switches easily between "forma" and "imago."

The survey of morphic language in Paul leaves a few unresolved issues. First, the concept of metamorphosis in Paul cannot be suf- 
ficiently explained from a supposed profusion of this concept in Greco-Roman or Jewish-apocalyptic sources. Second, scholars either

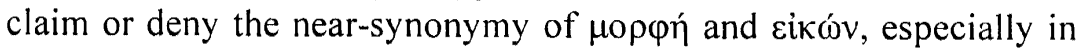
the Philippian hymn, but have failed to supply good grounds. Finally, the extent and coherence of Paul's morphic language call for elucidation. All these issues may profit from a comparison between Paul's morphic language and that of Philo, Paul's near-contemporary fellow-Jew, no less Hellenized than Paul. An analysis of morphic language in the latter will show, on the one hand, that the language of $\mu о \rho \varphi \eta$ is too diverse to provide clear parallels for Paul's morphic language, but, on the other hand, that it is the specific link between $\mu$ o$\varphi \eta$ and $\varepsilon i \kappa \omega v$ which may provide a way forward. Perhaps Paul's emphasis on Christ-believers being or becoming similar in form ( $\sigma 0$ $\mu$ $\mu \circ \rho \varphi \circ$ ) to the image of God will then also become more understandable.

\section{b. Morphic Language in Philo}

The terminology of form in Philo does not constitute a single, coherent theme, nor is "metamorphosis" a philosophical technical term in his writings. However, it is possible to detect five different applications of morphic language in Philo. In the following, I shall not give an exhaustive survey of all passages, as in Paul, but distinguish between the various applications and illustrate them with the most important examples.

\section{Anthropomorphism}

The broad range of applications of Philo's morphic language becomes clear immediately from the first cluster of passages. Their common theme is the criticism of an anthropomorphic understanding of God. In his commentary on the image of God in Gen. 1:26, Philo warns his readers against interpreting the likeness between God and man wrongly: "Let no one represent the likeness as one to a bodily

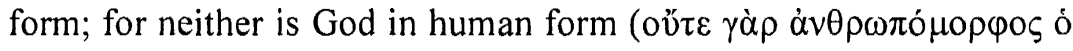
$\theta \varepsilon$ ó $)$, nor is the human body God-like" (De opificio mundi 69). According to Philo, "God is not only not in the form of man, but belongs to no class or kind" (Legum allegoriae I 37). A clear polemic is visible in Philo's writings against pagan anthropomorphic concepts of God, which threaten a proper understanding of God. In his com- 
mentary on Num. 23:19, "God is not a man," Philo states: “... we think of the blessed and the immortal in terms of our own natures. We shun indeed in words the monstrosity of saying that God is of

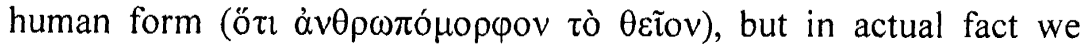
accept the impious thought that He is of human passions" (De sacrificiis Abelis et Caini 95). In very emphatic terms, Philo turns against anthropomorphic statements about God: "They are utterly monstrous inventions of men who would overthrow great virtues like piety and reverence by representing $\mathrm{Him}$ as having the form and passions of mankind" (De plantatione 35). ${ }^{23}$ The equally despicable opposite of such anthropomorphism is for a human being to claim to possess the form of a particular god, as Gaius Caligula did: "Falsely does he call himself Paean, let him cease once and for all to mimic the true Paean, for a form of a god ( $\theta \varepsilon 0 \tilde{v} \mu \rho \rho \varphi \eta ́)$ cannot be counterfeited as a coin can be" (Legatio ad Gaium 110-111).

There is only one form of anthropomorphism which Philo describes in a positive way, and that is where God reveals himself to human beings in the form of an angel or even in the form of man, the mode in which he appears in particular Old Testament narratives:

To the souls indeed which are incorporeal and are occupied in His worship it is likely that $\mathrm{He}$ should reveal Himself as $\mathrm{He}$ is, conversing with them as friend with friends; but to souls which are still in a body, giving Himself the likeness of angels, not altering His own nature, for $\mathrm{He}$ is unchangeable, but conveying to those which receive the impression of His presence a semblance in a different form, such that they take the image to be not a copy, but that original form itself ( $\dot{\alpha} \lambda \lambda \dot{\alpha} \delta o ́ \xi \alpha v \dot{\varepsilon} v-$

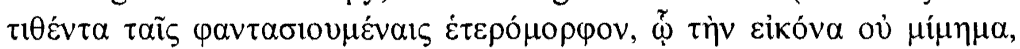

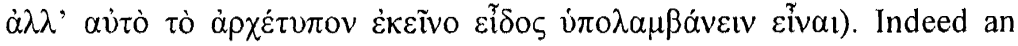
old saying is still current that the deity goes the round of the cities, in the likeness now of this man now of that man, taking note of wrongs and transgressions. (De somniis I 232-233, 238)

Interestingly, in support of this anthropomorphic, or rather angelomorphic revelation of God to human beings, Philo clearly alludes to Odyssey XVII 485. Similarly, the strangers who visit Abraham are

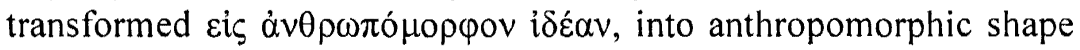

\footnotetext{
${ }^{23}$ For Philo's criticism of anthropomorphic views on God, see further De posteritate Caini 2-4; Quod deus sit immutabilis 55-56, 59; De confusione linguarum 135; De congressu eruditionis gratia 115 ; De mutatione nominum 54-55.
} 
(De Abrahamo 113). But for comparison with the notion of metamorphosis in Paul, this is a transformation in the "wrong direction," from God or angel to man, and for this reason these instances do not provide a useful parallel for Paul's notion of human beings transforming into the image of God. ${ }^{24}$

\section{The Forms of the Soul}

A further, different, application of Philo's morphic language is revealed in his discussion of the forms or forming of the human soul. In one passage Philo refers to the manifold forms and divisions of the soul, in which it is virtually impossible for the divine Spirit to abide (Quod deus sit immutabilis 2). In another, he talks about God

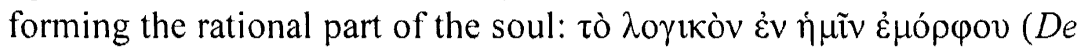
fuga et inventione 68-69). Indeed, in Philo's view, this forming was in accordance with the divine image: the dominant part of the soul, "the rational spirit-force within us ... was shaped according to the ar-

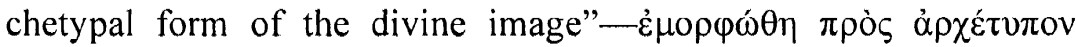

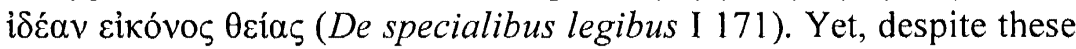
similarities, there is no talk in Philo of metamorphosis back into the image of God, so that even this application of morphic language does not throw sufficient light on that of Paul. To be sure, Philo does say something about moulding and forming "the soul into the approved standard, into the form of true goodness itself' (De specialibus legibus IV 196), but does not link this with the image of God.

\section{The Forms of the Cosmos}

Philo speaks not only of the forms of the soul, but also, in a cosmological-philosophical way, of the forms of the cosmos. This is not surprising, as this fits Philo's Platonizing style. In De specialibus legibus he clearly conducts a polemic against those who question the validity of Plato's doctrine of the incorporeal ideas or forms:

Just as anything crushed has lost its quality and form and may be

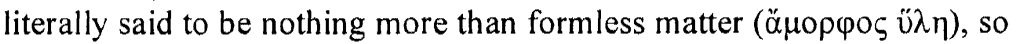
the creed which abolishes the Forms confuses everything and reduces it

\footnotetext{
${ }^{24}$ For such transformations, see further De Abrahamo 118. For the allegorical figure of nobility taking on human shape, see De virtutibus 195 . Yet another aspect of Philo's use of the language of anthropomorphism, which serves to underline the variety of his morphic language, is his description of the bad man as a beast with anthropomorphic features. See De vita Mosis I 43; and De Abrahamo 32-33.
} 
to the pre-elemental state of existence, that state devoid of form and

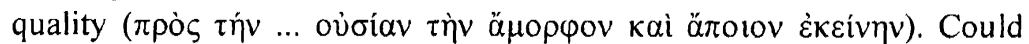
anything be more preposterous than this? For when out of that confused matter God produced all things, He did not do so with His own handiwork, since His nature, happy and blessed as it was, forbade that $\mathrm{He}$ should touch the limitless chaotic matter. Instead $\mathrm{He}$ made full use of the incorporeal potencies well denoted by their name of Forms to

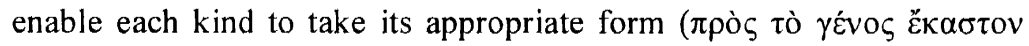

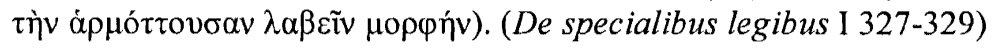

In this way Philo defends Plato's theory of forms, and in several cosmological passages in Philo this language can be seen at work. In De fuga et inventione 12, for instance, Philo reflects on the divine Logos, "by which each thing that exists has received its form ( $\mu \varepsilon \mu$ ó $\rho \varphi \tau \alpha \imath)$. Accordingly from the outset form in perfection accompanies the things that come into being, for it is an impress and image ( the terminology of form and image, this specific philosophical language does not really help us to understand Paul's reflection on the metamorphosis of human beings into the image of God. ${ }^{25}$

\section{The Specific Language of Metamorphosis}

The lack of true parallels to Paul's concept of metamorphosis is highlighted by the fact that, in Philo, there is as yet no specific fixed technical terminological meaning of metamorphosis. As noted above, the terminology of metamorphosis in Greek is late, and its occurrence before the first century CE rather limited.

This state of affairs is reflected in Philo's unspecific and vague use of the terminology of metamorphosis. Along the lines of his positive use of anthropomorphism outlined above, Philo speaks about angels who, despite their spiritual substance, often "imitate the forms of men

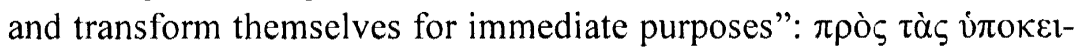

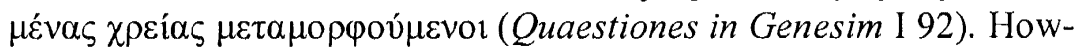
ever, Philo equally talks about the metamorphosis of Moses into a

${ }^{25}$ For morphic language in a cosmological context in Philo, see further also De somniis II 45. See also the language of transmutation of the cosmos and its forms, inspired by Euripides' line "Naught that is born doth ever die, | Its severed parts together fly, | And yield another form" (Euripides, frag. 839), in Legum allegoriae I 7 and De aeternitate mundi 5-6. For the decline of the forms and faculties of mankind throughout this cosmic process, see De opificio mundi 140-141 but without any hint at man's reconfiguration through a metamorphosis into the image of God. 


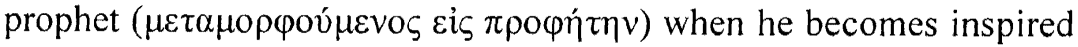
(De vita Mosis I 57); about the undesirable metamorphosis of the works of nature by defiled hand (Quaestiones in Exodum 2, frag. 1); about the transformation of piety into either superstition or impiety (De specialibus legibus IV 147); and, finally, about Gaius Caligula

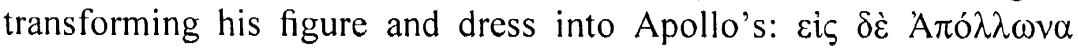

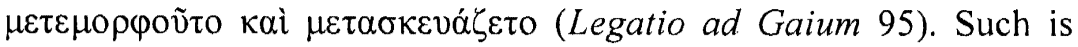
Philo's usage of the terminology of metamorphosis, and this confirms the impression that neither his morphic language in general, nor his specific usage of metamorphosis, is really parallel to that of Paul. As we shall see, it is rather his everyday, down-to-earth discourse about the "forms of images" which seems to be useful for understanding what is going on in Paul's morphic language.

\section{The Forms of Images}

In a very natural way, Philo repeatedly talks of the forms of images. He speaks of men who employ "sculpture and painting to form

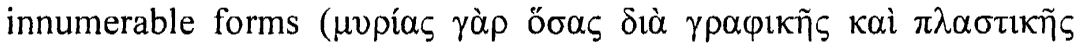
$\mu о \rho \varphi \omega ́ \sigma \alpha v \tau \varepsilon \zeta$ i $\delta \dot{\varepsilon} \alpha \varsigma)$ which they have enclosed in shrines and temples and after building altars have assigned celestial and divine honours to idols of stone and wood and suchlike images, all of them lifeless things" (De decalogo 7) ${ }^{26}$ In most passages such as this, Philo does

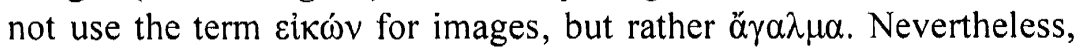
some passages do indeed contain the terminology of both zikóv and

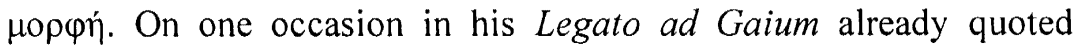
earlier, Philo talks about the Jews who "carry ( $\dot{\alpha} \gamma \alpha \lambda \mu \alpha \tau$

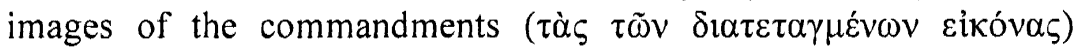
enshrined in their souls. Then as they contemplate their forms thus

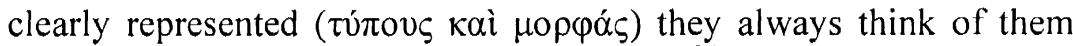
with awe" (Legatio ad Gaium 210-211). ${ }^{27}$ In this passage, the

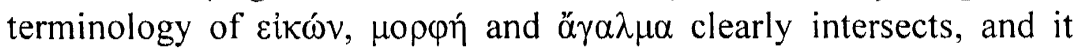
does so because of the ordinary manner of speaking about images having forms.

The same occurs in another passage in Philo's Legatio ad Gaium, when Philo describes how Gaius Caligula

${ }^{26}$ Cf. further De decalogo 66 and 72; De specialibus legibus II 255-256; De vita contemplativa 7.

${ }^{27}$ Cf. also Legatio ad Gaium 290 and 299. 
took possession of the synagogues in the other cities after beginning with those of Alexandria, by filling them with images and statues of

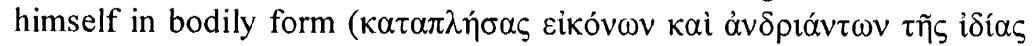

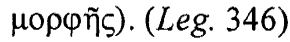

Here, too, images and bodily forms are mentioned in one breath. This common language of the forms of images and statues is present in many authors, as will be demonstrated in the next section. After that, I shall show how this non-philosophical, general morphic language throws light on that of Paul.

\section{c. The Images and their Forms}

The view that images have forms is attested in many Greek sources,

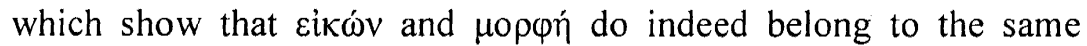
semantic-conceptual field. ${ }^{28}$ Dionysius of Halicarnassus $\left(1^{\text {st }}\right.$ cent. $\mathrm{BCE}$ ), for instance, gives a description of the procession of a Roman festival in which images appear to have $\mu о \rho \varphi \alpha i$ :

Last of all in the procession came the images of the gods ( $\alpha i \tau \tilde{i} v \theta \varepsilon \tilde{\omega} v$

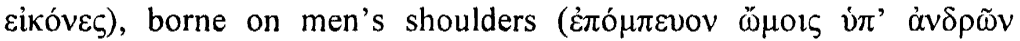

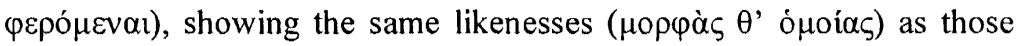
made by the Greeks and having the same dress, the same symbols, and the same gifts which tradition says each of them invented and bestowed on mankind. (Dionysius Halicarnassensis, Antiquitates Romanae VII 72.13)

We may note in passing that the idea of the images being "borne on men's shoulders" again emphasizes the observation above that Paul's talk of "bearing the image" of the earthly and heavenly man in 1 Cor. 15:49 has its background in the pagan practices of carrying around statues of the gods. However, what is key here is that these images of the gods are said to possess forms ( $\mu \rho \rho \varphi \alpha ́ s)$.

\footnotetext{
${ }^{28}$ For that reason I strongly disagree with Fee, Pauline Christology, p. 378, who claims, on the basis of J.H. Moulton and G. Milligan's The Vocabulary of the Greek Testament, London 1930: "Mo $\varphi \eta$ (...) denotes 'form' or 'shape' not usually in terms of the external features by which something is recognized but of those characteristics and qualities that are essential to it. Hence, it means that which truly characterizes a given reality." Cf. also $379 \mathrm{n}$. 29: "The improbability of genuine semantic overlap can especially be seen in the fact that the two words

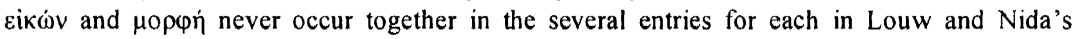
Greek-English Lexicon of the New Testament Based on Semantic Domains." However, it would be better practice to decide the question of their synonymy or semantic-conceptual overlap on the basis of the Online Thesaurus Linguae Graecae Digital Library (TLG®).
} 
This is also apparent from several passages in Plutarch. In De Alexandri magni fortuna aut virtute, Plutarch describes the proposal of Stasicrates, the master-sculptor, to cut out Alexander's image in Mount Athos, which has an almost human form:

"But I, your majesty," said he, "have conceived the project of placing your likeness in living and imperishable material, with roots that are everlasting and weight immovable and unshakable. For Mount Athos in Thrace, in that part where is its highest and most conspicuous summit, has well-proportioned surfaces and heights, limbs and joints and

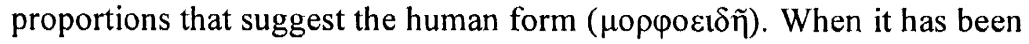
properly carved and worked into shape ( $\sigma \chi \eta \mu \alpha \tau i \sigma \theta \varepsilon i \xi)$, it can be called

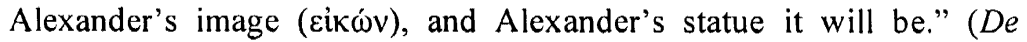
Alexandri magni fortuna aut virtute 335C-D; cf. Lucianus, Pro imaginibus 9)

In another passage, Plutarch uses the phrase "image of the form" when he remarks that the Spartan king Agesilaus did not leave behind any statue or picture of himself :

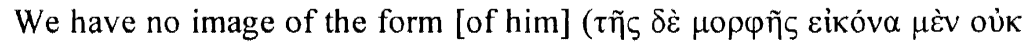
$\check{\varepsilon}^{\prime} \chi 0 \mu \varepsilon v$ ), for he himself would not consent to one, and even when he lay dying forbade the making of "either statue or picture" of his person, but he is said to have been a little man of unimposing presence. (Agesilaus 2.2)

In this case, "form" does not refer to the form of the image itself, but to the form of the person whom it represents. Normally, however, "form" would refer first and foremost to the forms of the image.

The terms "image" and "form" concur not only in pagan Greek writings, ${ }^{29}$ but also in Jewish writings, ${ }^{30}$ and in a plethora of earlyChristian sources. ${ }^{31}$ Among the Jewish sources, there is a very telling example in book III of the Sibylline Oracles, in which the

${ }^{29}$ For other examples of the concurrence of "image" and "form," see: Aristotle, Politica 1340a 25; Aristotle, Poetica 1448b 11; Plutarch, frag. 158 (ed. Sandbach); Lucian, Adversus indoctum et libros multos ementem 21; Alexander of Aphrodisias, In Aristotelis metaphysica

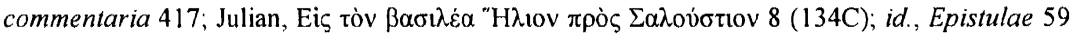
(ed. Bidez-Cumont $=$ Wright [Loeb] 48, 443B).

${ }^{30}$ Philo, Legatio ad Gaium 210-211 and 346, already discussed above; Josephus, Ant. VI 333 and, already referred to above, $A p$. II 190-191

${ }^{31}$ See, e.g., Or. Sib. VIII 378-379; Acta Joannis 28; Justin Martyr, Apologia 63.16 and 64.5; Irenaeus, Adversus haereses I 1.15; 8.1; 16.3; Ps-Clement, Homiliae XI 5.1; Origen, Commentariorum series in evangelium Matthaei 161; Corpus Hermeticum. Poimandres 12; Hippolytus, Refutatio omnium haeresium V 16.10; VI 14.5;20.1; 42.6. 
terminology of image and form is bound up with an allusion to the passage on the image of God in Gen. 1:26-27. In this instance the readers are addressed as follows:

Men, who have the form which God moulded in his image

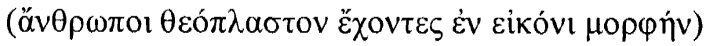

why do you wander in vain, and not walk the straight path

ever mindful of the immortal creator? (III 8-10)

The phrase "having the form which God moulded in his image" clearly shows that "form" and "image" belong to the same semanticconceptual field.

I finish with a very striking example from Celsus, which demonstrates that, from his pagan perspective, Celsus could easily draw the language of God's image from Gen. 1:26 into the ordinary parlance of images which are endowed with forms. In this passage, which has come down to us through Origen, Celsus criticizes the Christians because

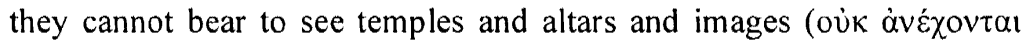

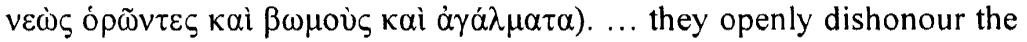
images. If what they mean is that an image of stone or wood or bronze or gold which some man or other has wrought cannot be a god, their wisdom is ludicrous. Who but an utter infant imagines that these things are gods and not votive offerings and images of gods? But if they mean that we ought not to suppose that images are divine ( $\varepsilon \dot{i} \delta^{\prime}$ ö $\tau \imath \mu \eta \delta \dot{\varepsilon} \theta \varepsilon i ́ \alpha \zeta$

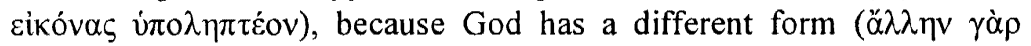
Eivol $\theta \varepsilon \circ \tilde{v} \mu о \rho \varphi \eta v)$, as the Persians also maintain [cf. Contra Celsum VII 62: Herodotus II 131], they [i.e. the Christians] have unwittingly refuted themselves. For they say that "God made man his own image"

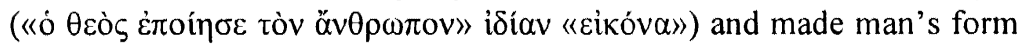

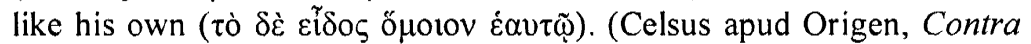
Celsum VII 62 trans. Chadwick; cf. VI 63).

As in the passage from Josephus' Contra Apionem quoted earlier (see $\S 2 \mathrm{a}$ above), the images of the gods are contrasted with the form of God, which is different from the forms of these images. Here, too, the forms are those which belong to images. It is within this common sense of images and their forms that Celsus also understands the Greek wording of Gen. 1:26-27 and, for this reason, believes that the Christians contradict themselves. If the form of God is different from the forms of the images of the gods, then the Christians refute 
themselves by holding that God made man in his own image and form.

Later on in his Contra Celsum, Origen answers Celsus' criticism in exactly the same language of image and form. According to Origen,

we [i.e. the Christians] do not suppose that the images are divine

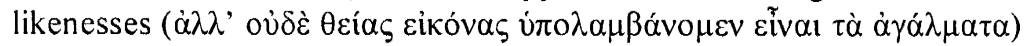
because we do not depict in any form a God who is invisible and

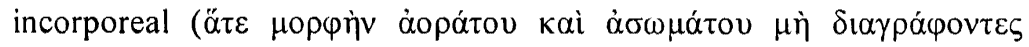
$\theta \varepsilon 0 \tilde{v})$. But Celsus supposes that we fall into contradicting ourselves when we say that God does not possess human form and when we believe that God made man His own image and made him in the image of God. My reply to this, as I also said earlier [VI 63], is that the part which is "in the image of God" is to be found preserved in the rational soul which has the capacity for virtue. And yet Celsus, failing to see the difference between God's image and that which is made after the image of God, says that we affirm "God made man his own image and made man's form like his own." To this we replied earlier. (Contra Celsum VII 66)

Celsus' attack and Origen's reply show that, in a very natural, fluid way, both pagans and Christians share the same language of images and their forms, even when talking about the image of God.

\section{Concluding Observations}

The parallels for Paul's morphic language do not seem to lie in philosophical reflections on forms, whether the forms of the soul, or the forms of Plato's theory. Nor is the Greek concept of metamorphosis sufficient to explain Paul's notion of transformation into the image of God. It seems, rather, that it is the commonplace, daily understanding of images being endowed with forms which can throw light upon the three problematic issues identified in the inventory of Paul's morphic language: (a) the issue of the "form of God," (b) the issue of transformation, and, finally, (c) the issue of the coherence of Paul's morphic language in general. In each case, as I shall briefly argue, the conventional manner of speaking about images and their forms seems to furnish the appropriate background. 


\section{a. "Being in the Form of God"}

Against the background of the common idiom of the forms of images, the depiction of Christ as the one ôs $\dot{\varepsilon} v \mu \rho \rho \varphi \tilde{n} \theta \varepsilon \circ \tilde{v} \dot{v} \pi \dot{\alpha} \rho \chi \omega v$, "who was in the form of God" (Phil. 2:6) can have two meanings.

(1) First, indeed, as Dunn believes, "form" here could be the form of the image of God. This meaning is best illustrated by the rendition of Gen. 1:26-27 in Sib. Or. III 8, already quoted: "Men, who have the

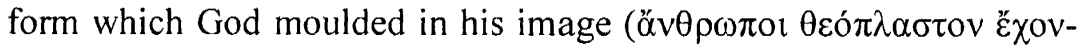

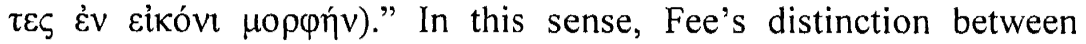
"form" and "image" runs contrary to the way in which (the combination of) these terms would have been commonly understood in Antiquity.

This, however, in no way decides the matter of whether this Adam Christology in Phil. 2:6 applies only to Christ's post-incarnational, earthly existence, as Dunn believes, or also to his pre-existence. I am inclined to think that acknowledging that Adam Christology is present in Phil. 2:6 does not preclude the possibility that this passage refers to the pre-existent Christ. After all, Adam II in 1 Corinthians

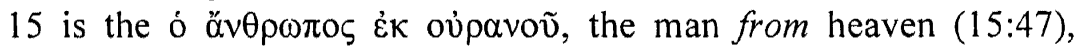
which seems to imply that Paul took this heavenly man as pre-

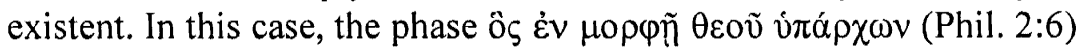

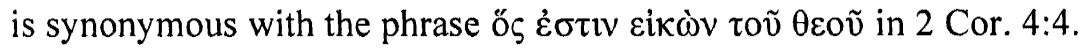
I do not regard it as compelling that the latter phrase should only apply to Christ on the basis of his earthly life (pace Fee, Pauline Christology, pp. 519-520). ${ }^{32}$ As in Col. 1:15, this phrase could well refer to the pre-existent state of the man from heaven. This view that Adam II, in his capacity as the heavenly man, was pre-existent also accords very well with Philo's thoughts about the heavenly man, who is created after the image of God and precedes the earthly man. ${ }^{33}$ In Philo, however, the heavenly man, being created after the image of

${ }^{32} \mathrm{Cf}$. Fee, Pauline Christology, pp. 522-523: "Paul uses this language [the language of

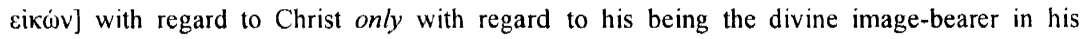
incarnation, not with regard to his preexistence."

${ }^{33}$ See G.H. van Kooten, "The Two Types of Man in Philo of Alexandria and Paul of Tarsus: The Anthropological Trichotomy of Spirit, Soul and Body," in: Ch. Jedan/L. Jansen (eds), Philosophische Anthropologie in der Antike, Frankfurt etc. 2008; an abridged version, entitled "The Anthropological Trichotomy of Spirit, Soul and Body in Philo of Alexandria and Paul of Tarsus," is published in: M. Labahn/O. Lehtipuu (eds), Anthropology in Context. Studies on Anthropological Ideas within the New Testament and its Ancient Context, Louvain 2008. 
God, is distinct from the image, which is identical with the Logos, the second God. Here the hierarchy thus runs as follows (from the top down): (i) God, (ii) Image = Logos, and (iii) heavenly man, created after the image. In Paul, however, the heavenly man and the image seem to coincide, and for this reason Paul can speak of "bearing the image of the heavenly man" (1 Cor. 15:49).

(2) Secondly, however, it could also be the case that the term

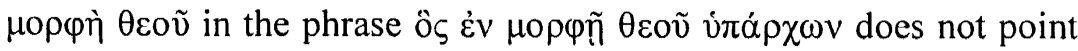
to the image of God, but refers to the form of God in precisely the same way as we have seen it used in Josephus and Celsus. According to Josephus, God's "form and magnitude surpass our powers of

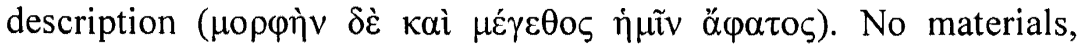
however costly, are fit to make an image of $\operatorname{Him}(\pi \tilde{\alpha} \sigma \alpha \mu \dot{\varepsilon} v \tilde{v} \lambda \eta \pi$ jò̀

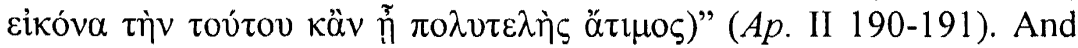
according to Celsus, the Christians "mean that we ought not to

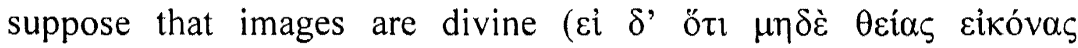

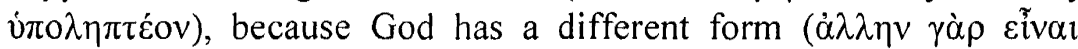

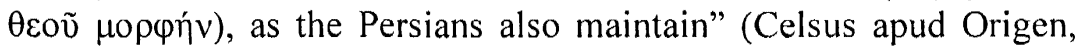
Contra Celsum VII 62). Here too, however, I would contend, the language of God's form is occasioned by an explicit contrast between the form of God and the images of the gods, so that the same semantic-conceptual field of images and their forms is still at work. It is true, as Fee suggests, that in this case the "form of God" in Phil. $2: 6$ takes on the meaning of his divinity, so that the pre-existent Christ is said to share in God's form of divinity. ${ }^{34}$ But that again, I believe, is not so very different from the language of being the image of God. However one understands Phil. 2:6, the essential fact remains that this passage is part of Paul's Adam Christology, although the emphasis here seems to be on the pre-existent Adam from heaven.

\section{b. Metamorphosis}

As we have seen, one specific component of Paul's morphic language, the notion of metamorphosis into God's image, is only insufficiently explained by the background of Greek mythology and philosophy. The terminology of metamorphosis is late, with only a limited number of occurrences before the first century CE. As a

\footnotetext{
${ }^{34}$ Fee, Pauline Christology, pp. 376-381.
} 
survey of the few instances of this term in Philo shows, metamorphosis had not acquired a specific technical meaning for Philo. Nor is the notion of metamorphosis in Jewish apocalyptic texts fully parallel. The best way to understand metamorphosis in Paul is to regard it as a natural part of Paul's reflections on the image of God. As images and their forms are part of a common, everyday idiom in the Greek world, Paul's application of metamorphosis does not derive from a fixed concept, but rather evolves naturally from his focus on the image of God.

As I have sought to demonstrate elsewhere, the view that, by way of metamorphosis into the image of God, the Christ-believer is conformed more and more to the divine image does have an analogy in the Platonic ideal of becoming as much like God as possible (see, e.g., Plato, Theaetetus 176B); this progressive conformation seems to be without parallel in ancient Jewish thought. I would emphasize, however, that the terminology of metamorphosis is best understood as a natural consequence of the important place which Paul accords to the language of the image of God. In 2 Cor. 3:18 we have the full, explicit expression of Paul's idea of the metamorphosis into the image of God; this transforming process-as 2 Cor. 4:16 explainstakes place in the "inner man." In Rom. 12:2, Paul highlights that this metamorphosis comes to pass through the renewal of the mind (voṽs), which-as is apparent from Rom. 7:22-25-is synonymous with the "inner man." Although the term "image" is not repeated in Romans 12, it is presupposed, since already in Rom. 8:29 Paul refers to the process of taking on the same form as Christ's image. Both passages, 2 Corinthians 3 and Romans 12, are based on the logic of transforming into God's image.

\section{c. The Extent and Coherence of Paul's Morphic Language}

If indeed Paul's morphic language is rooted in his reflections on the image of God, it is also reversely the case that the full extent of Paul's conception of the image of God becomes visible in his morphic language. As we have seen, in the common idiom of images and their forms, "form" refers either to the form of the image itself, or to the form which the image represents. Both meanings are possible and depend upon the context. Similarly, Paul's morphic language is equally ambiguous. His notion of metamorphosis into the image of 
God refers both to the form inherent in the divine image and to the form which the subject takes on as its own. This ambiguity is nicely captured in the compound terms ov́ $\mu \mu \rho \varphi о \varsigma$ ("having the same form,

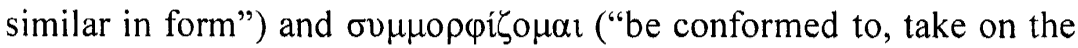
same form as"); in Greek they occur almost exclusively in Paul and in literature dependent upon him, ${ }^{35}$ and-as we can deduce from our survey-constitute the most frequent expression of Paul's morphic language (Phil. 3:10, 21; Rom. 8:29). If man takes on the same form as Christ, Christ can reciprocally also be said to take form within

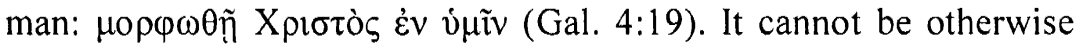
than that this process has something to do with the dynamics of Christ's alternation between $\dot{\varepsilon} v \mu \circ \rho \varphi \tilde{~} \theta \varepsilon \circ \tilde{v}$ vं $\alpha \dot{\rho} \chi \omega v$ (Phil. 2:6) and

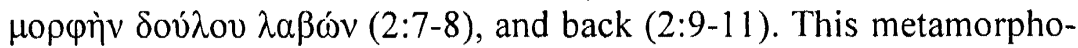
sis of Christ now seems to be mirrored in the metamorphosis of Christ-believers into the image of God (2 Cor. 3:18; Rom. 12:2). Paul's morphic language is remarkably coherent and extensive. Whereas the terminology of form in Philo does not constitute a single, coherent theme but has rather diverse applications, in Paul it seems to support one of the central tenets of his theology - his Adam Christology and, more precisely, his reflections on the image of God.

\footnotetext{
${ }^{35}$ The main exceptions among the more than 700 occurrences in the extant Greek literature are Nicander, Theriaca 321; Heraclitus, Allegoriae 77.3; and Pseudo-Lucian, Amores 39.
} 


\section{Bibliography}

T. Ballauff, "Metamorphose," Historisches Wörterbuch der Philosophie 5 (1980), pp. 1177 1179

J. Balty/F. Briquel Chatonnet, "Nouvelles mosaïques inscrites d'Osrhoène," Monuments et Mémoires 79 (2000), pp. 31-72

G. Bowersock, "Notes on the New Edessene Mosaic of Prometheus," Hyperboreus 7 (2001), pp. $411-416$

J.N. Bremmer, Greek Religion \& Culture. The Bible and the Ancient Near East, Leiden 2008 (forthcoming)

J.H. Charlesworth (ed.), The Old Testament Pseudepigrapha 1-2, Garden City 1983-1985

J.D.G. Dunn, Romans, Dallas 1988

- Christology in the Making. A New Testament Inquiry into the Origins of the Doctrine of the Incarnation, London ${ }^{2} 1989$

- The Theology of Paul the Apostle, Edinburgh 1998

J. Engemann, "Nichtchristliche und christliche Ikonographie," in: A. Demandt/J. Engemann (eds), Konstantin der Grosse: Imperator Caesar Flavius Constantinus-Ausstellungskatalog, München 2007, pp. 281-294

G.D. Fee, Pauline Christology. An Exegetical-Theological Study, Peabody 2007

J. Haussleiter, "Deus internus," RAC 3 (1957), pp. 794-842

J. Jervell, "Imagines und Imago Dei: aus der Genesis-Exegese des Josephus," in: O. Betz/K. Haacker/M. Hengel (eds), Josephus-Studien. Untersuchungen zu Josephus, dem antiken Judentum und dem Neuen Testament: Otto Michel zum 70sten Geburtstag gewidmet, Göttingen 1974, pp. 197-204

H. Kaiser-Minn, Die Erschaffung des Menschen auf den spätantiken Monumenten des 3. und 4. Jahrhunderts, Münster 1981

G.H. van Kooten, "Pagan and Jewish Monotheism according to Varro, Plutarch and St Paul: The Aniconic, Monotheistic Beginnings of Rome's Pagan Cult-Romans 1:19-25 in a Roman Context," in: A. Hilhorst/É. Puech/E. Tigchelaar (eds), Flores Florentino. Dead Sea Scrolls and Other Early Jewish Studies in Honour of Florentino Garcia Martinez, Leiden 2007, pp. $633-651$

- "The Two Types of Man in Philo of Alexandria and Paul of Tarsus: The Anthropological Trichotomy of Spirit, Soul and Body," in: Ch. Jedan/L. Jansen (eds), Philosophische Anthropologie in der Antike, Frankfurt etc. 2008

- "The Anthropological Trichotomy of Spirit, Soul and Body in Philo of Alexandria and Paul of Tarsus," in: M. Labahn/O. Lehtipuu (eds), Anthropology in Context. Studies on Anthropological Ideas within the New Testament and its Ancient Context, Louvain 2008

J.F. Kutsko, "Ezekiel's Anthropology and Its Ethical Implications," in: M.S. Odell/J.T. Strong (eds), The Book of Ezekiel. Theological and Anthropological Perspectives, Atlanta 2000, pp. 119-141

J.R. Levison, Portraits of Adam in Early Judaism. From Sirach 102 Baruch, Sheffield 1988.

R.P. Martin, Carmen Christi. Philippians ii.5-1/ in Recent Interpretation and in the Setting of Early Christian Worship, Cambridge 1967

J.M. Miller, "In the 'Image' and 'Likeness' of God," JBL 91 (1972), pp. 289-304

A. Schüle, "Made in the "Image of God": The Concepts of Divine Images in Gen 1-3," ZAW 117 (2005), pp. 1-20

D. Steenburg, "The Case against the Synonymity of Morphē and Eikōn," JSNT 34 (1988), pp. $77-86$ 